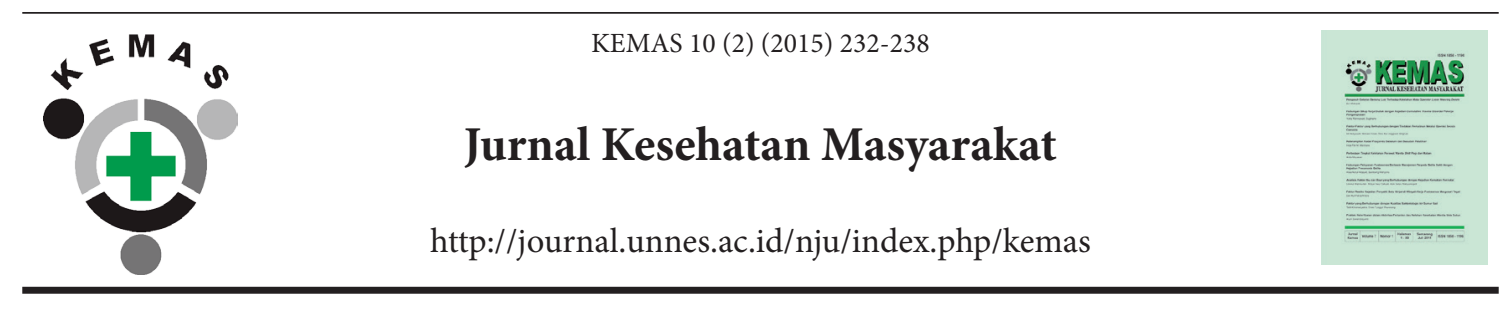

\title{
STUDI METODE PENAMBAHAN PERAK NITRAT PADA SARINGAN KERAMIK TERHADAP Escherichia coli PADA AIR MINUM
}

\author{
Ariyanto Nugroho ${ }^{1 凶}$, Adi Heru Sutomo ${ }^{2}$, Susi Iravati ${ }^{2}$, Sarto $^{3}$, Yulia Rina Wijaya ${ }^{4}$ \\ ${ }^{1}$ Program Studi Kesehatan Masyarakat, Universitas Respati Yogyakarta \\ ${ }^{2}$ Fakultas Kedokteran, Universitas Gadjah Mada Yogyakarta \\ ${ }^{3}$ Fakultas Teknik, Universitas Gadjah Mada Yogyakarta \\ ${ }^{4}$ Yayasan SHEEP Indonesia
}

\section{Info Artikel}

Sejarah Artikel:

Diterima 6 November 2014

Disetujui 28 November 2014

Dipublikasikan Januari 2015

Keywords:

Drinking water;

Ceramic filter;

E.coli densely;

Natural disasters.

\begin{abstract}
Abstrak
Problematika air tercemar mikrobiologis di Yogyakarta berdasar hasil pemantauan rutin oleh Dinas Kesehatan Kota Yogyakarta pada tahun 2011 menunjukkan bahwa pada parameter mikrobiologis terdapat 596 (67\%) sumber air bersih (sumur) penduduk belum memenuhi syarat sesuai Permenkes 492/MENKES/PER/IV/2010, demikian juga pada tahun 2010 dan 2009 masing masing 68,8\% dan $63,2 \%$ dari sampel yang diperiksa, sedangkan untuk pemeriksaan terhadap air perpipaan (PDAM) pada tahun 2011 masih terdapat 8,9 \% dari sampel yang tidak memenuhi syarat. Hal tersebut terjadi pada pemukiman padat penduduk yang disebabkan keterbatasan lahan sehingga jarak antara peresapan jamban dengan sumur penduduk kurang dari persyaratan. Penggunaan Filter Keramik sebagai pengolahan air pada tingkat rumah tangga telah banyak dipelajari dan diteliti Riset filter keramik dikembangkan untuk persiapan keadaan darurat bencana dan pemukiman padat penduduk. Penelitian ini dilakukan pada tahun 2013-2014 dengan menggunakan rancangan analitik observasional, dengan pendekatan pre test-postest group design dengan analisis kuantitatif eksperimen dilaksanakan didalam laboratorium. Hasil menunjukkan tidak terdapat perbedaan pada metode penambahan perak nitrat ke dalam saringan keramik, sehingga pengembangan saringan keramik lebih mudah dan sangat memungkinkan menjadi alternatif untuk penyediaan air bersih dan layak konsumsi terutama pada keadaan darurat kebencanaan
\end{abstract}

\section{STUDY METHOD OF SILVER NITRATE IN ADDITION OF CERAMIC FILTERS WITH Escherichia coli IN DRINKING WATER}

\begin{abstract}
Problems of microbiologically contaminated water in Yogyakarta based on the results of routine monitoring by the City Health Office Yogyakarta in 2011 showed that the microbiological parameters are 596 (67\%) of clean water sources (wells) population is not eligible in accordance Permenkes 492 / Menkes / Per / IV / 2010, as well as in 2010 and 2009, respectively $68.8 \%$ and $63.2 \%$ of the samples examined, while for the examination of water piped (PDAM) in 2011, there are 8.9\% of the sample were not eligible. It occurs in a densely populated residential area due to limited so that the distance between the infiltration wells latrine with a population less than the requirement. Use of Ceramic Filter as water treatment at household level has been widely studied and researched Research ceramic filters developed for the preparation of emergency response and densely populated area. This study used observational analytic design, the pretest-posttest approach to group design with quantitative analysis experiments were carried out in the laboratory. The results showed no difference in the method of adding silver nitrate into the ceramic filters, so that the development of ceramic filters easier and it is possible to be an alternative to the provision of clean and potable water, especially in an emergency disaster.
\end{abstract}

(C) 2015 Universitas Negeri Semarang 


\section{Pendahuluan}

Air minum adalah air yang kualitasnya memenuhi syarat kesehatan dan dapat langsung diminum, syarat kesehatan yang dimaksud adalah mikrobiologi, kimia, fisika, dan raidoaktif (Amber, 2009) Salah satu parameter kualitas air yang harus diperhatikan adalah bahaya biologis. Mikroorganisme yang digunakan sebagai indikator adalah jenis Escherechia coli (E. coli) atau coli tinja. E. coli terdapat dalam tinja sehingga dapat menjadi indikator yang menunjukkan air tercemar oleh tinja manusia atau hewan berdarah panas. Berdasarkan Permenkes 492/ MENKES/PER/IV/2010 maka nilai Most Probability Number (MPN) E coli bernilai nol. Hasil pemantauan rutin oleh Dinas Kesehatan Kota Yogyakarta pada tahun 2011 menunjukkan bahwa pada parameter mikrobiologis terdapat 596 (67\%) sumber air bersih (sumur) penduduk belum memenuhi syarat sesuai Permenkes 492/ MENKES/PER/IV/2010, demikian juga pada tahun 2010 dan 2009 masing masing 68,8\% dan $63,2 \%$ dari sampel yang diperiksa, sedangkan untuk pemeriksaan terhadap air perpipaan (PDAM) pada tahun 2011 masih terdapat 8,9\% dari sampel yang tidak memenuhi syarat.

Salah satu cara yang mudah diaplikasikan untuk mengatasi masalah mikrooorganisme yaitu dengan pembuatan filter, filter air dirasa sangat efektif karena cara kerja yang mudah yaitu cukup menuangkan air baku yang akan disaring menjadi air minum. Salah satu jenis saringan yang digunakan yang terbuat dari bahan keramik dan merupakan salah satu teknologi tepat guna.

Saringan keramik bekerja dengan menuangkan air baku (dari sungai, danau, dll) ke dalam filter, lalu air terfiltrasi melalui keramik. Air menetes ke dalam penadah plastik dan pengguna dapat mengambil air dari penadah plastik. Saat ini di beberapa Negara sedang dikembangkan saringan keramik yang dikombinasikan dengan perak ke dalam saringan, dimana perak berfungsi sebagai bactericide. Aplikasi penggunaan perak sendiri merupakan salah satu inovasi baru dalam penyediaan air bersih, berdasar riset sebelumnya yang menyebutkan bahwa anti bakteri menggunakan perak mampu menurunkan lebih dari $5 \log 10 \mathrm{CFU} /$ ml S. aureus dan E. coli. (Jung, 2008) Peneli- tian tersebut dilakukan dilakukan dalam skala laboratorium untuk melihat aktifitas antibakteri ion perak. Hasil penelitian Brown (2008), yang menyelidiki efektifitas saringan keramik di Kamboja menunjukkan bahwa saringan keramik dapat Saringan keramik mereduksi $E$. coli dengan reduksi rata-rata $99 \%$ baik di laboratorium maupun pada percobaan di lapangan.

Kajian tentang filter dilakukan oleh lembaga SHEEP saat ini fokus pada desain saringan keramik yang meliputi, komposisi campuran, tekanan pengepresan, porositas yang terbentuk, dan flow rate, sedangkan untuk penelitian terkait aplikasi metode penambahan perak ke dalam saringan belum dilakukan. Berdasar pada uraian diatas maka, peneliti tertarik untuk melakukan kajian terhadap aplikasi perak nitrat $\left(\mathrm{AgNO}_{3}\right)$ pada saringan keramik. Penelitian tentang efek bakterisida perak terhadap bakteri telah banyak dilakukan, namun untuk metode penambahan perak ke dalam saringan keramik untuk mendapatkan hasil yang paling efektif dalam menurunkan E. Coli belum dilakukan.

\section{Metode}

Pada peneltian ini menggunakan rancangan analitik observasional, dengan pendekatan pre test-postest group design dengan analisis kuantitatif eksperimen dilaksanakan di dalam laboratorium untuk menguji aplikasi perak nitrat pada saringan keramik desain SHEEP sehingga diharapkan akan diketahui mekanisme aplikasi dan dosis yang paling efektif. Penelitian ini dilaksanakan di Laboratorium filter dan laboratorium Mikrobiologi Fakultas Kedokteran Universitas Gadjah Mada pada bulan Desember 2013-Agustus 2014.

Populasi pada penelitian ini adalah filter air yang didesain berjumlah 12 buah. Sedangkan sampel yang digunakan adalah total populasi. Pada penelitian ini dilakukan dilakukan pengulangan 5 kali pada setiap percobaan yang dilakukan, sehingga sampel pengujian kualitas air yang diperoleh adalah 60 sampel pengujian untuk pre test dan sejumlah 60 untuk post test

Pada penelitian ini, desain saringan keramik yang digunakan merupakan inovasi dari team peneliti di NGO SHEEP, yang memodifikasi dari bentuk pot filter menjadi candle filter. Komponen Filter Keramik SHEEP Indonesia 
terdiri atas:

Bahan keramik ini terdiri dari campuran grog, tanah liat dan sekam padi halus yang dicampur dengan larutan Perak Nitrat (Perak Koloid). Campuran berbentuk adonan ini kemudian dicetak dalam bentuk candle dan dibakar pada suhu $1.200^{\circ} \mathrm{C}$. Pembakaran Filter Keramik pada suhu tinggi ini membuat filter menjadi kuat dan mampu menahan aliran air. Saat sekam padi sebagai satu-satunya bahan organikterbakar sempurna pada proses pembakaran, mampu membentuk pori-pori di antara partikel-partikel keramik.Pori-pori tersebut memungkinkan air mengalir lebih cepat melalui filter. Meski demikian, aliran air melalui partikel-partikel keramik tetap mampu menyaring kotoran dan bakteri-bakteri patogen karena porositasnya yang kecil, yaitu antara $0.1-0.3 \mu \mathrm{m}$ (micron meter).

Perak juga berfungsi membunuh bakteri. Perak biasa digunakan di dunia medis sebagai desinfectant. Larutan perak pada Filter Air Keramik sangat penting untuk membunuh mikro organisme yang hidup di air.

Selain modifikasi dari sisi bentuk filter ini juga memodifikasi dari metode penambahan perak ke dalam filter yaitu: 1) Setelah candle filter terbentuk dicelupkan pada larutan perak nitrat selanjutnya dibakar kembali pada suhu $440^{\circ} \mathrm{C}$ guna memisahkan perak dan nitrat, 2) setelah candle filter terbentuk dicelupkan pada larutan perak nitrat selanjutnya dikeringkan secara alamiah dengan energi matahari, 3) pada pembuatan candle filter, Larutan perak nitrat menjadi bagian dari komposisi penyusun dan dibakar pada suhu $1200^{\circ} \mathrm{C}$.

Setelah pembakaran, filter berbentuk candle diisi dengan Arang aktif yang memiliki muatan positif berfungsi untuk mengikat virus \& kandungan kimia yang memiliki muatan negatif (seperti magnet yg menempel pada logam).

Setelah filter terbentuk dilakukan uji buble point test yaitu uji untuk menentukan besaran pori-pori pada filter dengan meniupkan udata bertekanan tinggi dan diamati gelembung yang pertama muncul dan tekanan terbesar yang membuat gelembung muncul merata diseluruh permukaan filter.

Komponen filter keramik bentuk candle tersebut diset dengan 2 kontainer plastik mas- ing-masing berkapasitas 13 liter, beserta tutup dan kran air pada kontainer bawah. Kontainer atas yang diisi dengan air sebelum difilter yang dasarnya telah dipasang 3 (tiga) filter candel untuk memperluas permukaan penyaringan.. Apabila satu filter memiliki debit 2-3 liter per jam, maka dengan 3 filter, debit air yang dihasilkan adalah 6-9 liter per jam. Kontainer bawah yang berisi air siap konsumsi memiliki kapasitas maksimal 13 liter.

Selanjutnya dilakukan pengujian mikrobiologi di laboratorium dengan menggunakan metode TBX yang spesifik untuk mengidentifikasi keberadaan $E$ coli pada air dan pengujian kandungan perak dengan metode AAS Serta kandungan Nitrat dengan spektrofotometer.

\section{Hasil dan Pembahasan}

Secara umum, Indonesia menjadi satu dari sedikit negara yang "ditakdirkan" memiliki sumber daya air berlimpah. Berbagai laporan mengenai kondisi neraca air Indonesia menunjukkan bahwa Indonesia masih mengalami surplus air. Meskipun demikian, terdapat beberapa pulau di Indonesia yang telah mengalami defisit air, pada dasarnya bahwa persoalan sumber daya air di Indonesia tidaklah disebabkan kelangkaan ketersediaan air, tetapi lebih kepada ketidakmampuan negara untuk mengelola sumber daya air. Kebijakan pembangunan yang terlalu bertumpu di Jawa, menyebabkan $65 \%$ penduduk Indonesia saat ini bermukim di pulau Jawa dengan daya dukung air yang semakin terbatas. Bukan sesuatu yang mengherankan jika Jawa mengalami defisit air.

Setiap hari kurang lebih 2.272 liter darah dibersihkan oleh ginjal dan sekitar 2,3 liter diproduksi menjadi urine. Selebihnya diserap kembali masuk ke aliran darah. Dalam kehidupan sehari-hari, air dipergunakan antara lain untuk keperluan minum, mandi, memasak, mencuci, membersihkan rumah, pelarut obat, dan pembawa bahan buangan industri. Ditinjau dari sudut ilmu kesehatan masyarakat, penyediaan sumber air bersih harus dapat memenuhi kebutuhan masyarakat karena persediaan air bersih yang terbatas memudahkan timbulnya penyakit di masyarakat. Volume rata- rata kebutuhan air setiap individu per hari 
Tabel 1. Pre test dan Pos test kandungan E. coli pada masing-masing filter.

\begin{tabular}{|c|c|c|c|c|c|c|c|c|c|c|c|c|c|c|c|}
\hline \multirow[b]{2}{*}{ Filter } & \multicolumn{3}{|c|}{ Pengulangan 1} & \multicolumn{3}{|c|}{ Pengulangan 2} & \multicolumn{3}{|c|}{ Pengulangan 3} & \multicolumn{3}{|c|}{ Pengulangan 4} & \multicolumn{3}{|c|}{ Pengulangan 5} \\
\hline & Pre & Post & Selisih & Pre & Post & Selisih & Pre & Post & Selisih & Pre & Post & Selisih & Pre & Post & Selisih \\
\hline $\mathrm{A}$ & 14.33 & 0.09 & 14.24 & 15.33 & 0.00 & 15.33 & 1.33 & 0.03 & 1.30 & 1.33 & 0.03 & 1.30 & 21.00 & 0.23 & 20.77 \\
\hline B & 42.33 & 0.07 & 42.26 & 10.67 & 0.00 & 10.67 & 2.33 & 0.03 & 2.30 & 1.67 & 0.03 & 1.64 & 14.67 & 0.17 & 14.49 \\
\hline $\mathrm{C}$ & 42.00 & 0.05 & 41.95 & 15.67 & 0.00 & 15.67 & 5.67 & 0.04 & 5.62 & 6.33 & 0.03 & 6.30 & 13.67 & 0.12 & 13.55 \\
\hline $\mathrm{D}$ & 27.33 & 0.01 & 27.33 & 11.00 & 0.08 & 10.92 & 0.33 & 0.01 & 0.32 & 1.67 & 0.01 & 1.65 & 14.00 & 0.02 & 13.98 \\
\hline E & 13.33 & 0.00 & 13.33 & 11.67 & 0.08 & 11.59 & 2.67 & 0.00 & 2.67 & 0.67 & 0.00 & 0.66 & 14.00 & 0.00 & 14.00 \\
\hline $\mathrm{F}$ & 7.67 & 0.00 & 7.67 & 20.67 & 0.00 & 20.67 & 5.00 & 0.00 & 5.00 & 0.67 & 0.00 & 0.66 & 17.00 & 0.00 & 17.00 \\
\hline G & 5.00 & 0.00 & 5.00 & 10.67 & 0.00 & 10.66 & 0.67 & 0.00 & 0.67 & 0.33 & 0.05 & 0.28 & 9.67 & 0.00 & 9.67 \\
\hline $\mathrm{H}$ & 14.67 & 0.00 & 14.67 & 35.33 & 0.00 & 35.33 & 0.67 & 0.00 & 0.67 & 0.67 & 0.01 & 0.66 & 15.67 & 0.00 & 15.67 \\
\hline I & 13.33 & 0.00 & 13.33 & 16.67 & 0.00 & 16.66 & 5.33 & 0.00 & 5.33 & 1.33 & 0.01 & 1.32 & 9.33 & 0.00 & 9.33 \\
\hline $\mathrm{J}$ & 21.00 & 0.00 & 21.00 & 15.67 & 0.00 & 15.66 & 0.33 & 0.00 & 0.33 & 1.67 & 0.01 & 1.65 & 8.00 & 0.00 & 8.00 \\
\hline K & 16.00 & 0.00 & 16.00 & 11.00 & 0.01 & 10.99 & 1.00 & 0.00 & 1.00 & 1.00 & 0.02 & 0.98 & 13.33 & 0.00 & 13.33 \\
\hline $\mathrm{L}$ & 22.00 & 0.00 & 22.00 & 8.67 & 0.00 & 8.66 & 0.67 & 0.00 & 0.67 & 2.33 & 0.03 & 2.30 & 12.33 & 0.00 & 12.33 \\
\hline
\end{tabular}

Sumber : data primer

berkisar antara 150-200 liter atau 35-40 galon. Kebutuhan air tersebut bervariasi dan bergantung pada keadaan iklim, standar kehidupan, dan kebiasaan masyarakat.

Coliform adalah golongan bakteri intestinal, yaitu hidup didalam saluran pencernaan manusia. Bakteri Coliform adalah bakteri indikator keberadaan akteri patogenik lain. Lebih tepatnya, bakteri coliform fekal adalah bakteri indikator adanya pencemaran bakteri patogen. Penentuan coliform fekal menjadi indikator pencemaran dikarenakan jumlah koloninya pasti berkorelasi positif dengan eberadaan bakteri patogen. Selain itu, mendeteksi coli- form jauh lebih murah, cepat, dan sederhana daripada mendeteksi bakteri patogenik lain. Contoh bakteri Coliform adalah, Escherichia coli dan Enterobacter aerogenes.

Jadi,coliform adalah indikator kualitas air. Makin sedikit kandungan coliform, artinya, kualitas air semakin baik. E. coli jika masuk ke dalam saluran pencernaan dalam jumlah banyak dapat membahayakan kesehatan. Walaupun E. Coli merupakan bagian dari mikroba normal saluran pencernaan, tapi saat ini telah terbukti bahwa galur-galur tertentu mampu menyebabkan gastroenteritis taraf sedang hingga parah pada manusia dan hewan.Sehing-

Tabel 2. Prosentase penurunan kandungan E. coli pada masing-masing filter.

\begin{tabular}{ccccccc}
\hline \multirow{2}{*}{ Filter } & \multicolumn{7}{c}{ Pengulangan } \\
\cline { 2 - 6 } & $\mathbf{1}$ & $\mathbf{2}$ & $\mathbf{3}$ & $\mathbf{4}$ & $\mathbf{5}$ & Rata-rata \\
\hline A & 99,36 & 99,99 & 97,70 & 97,73 & 98,91 & 98,74 \\
B & 99,83 & 100,00 & 98,62 & 98,45 & 98,83 & 99,15 \\
C & 99,88 & 99,99 & 99,26 & 99,50 & 99,16 & 99,56 \\
D & 99,97 & 99,27 & 95,96 & 99,23 & 99,85 & 98,85 \\
E & 100,00 & 99,33 & 100,00 & 99,67 & 100,00 & 99,80 \\
F & 100,00 & 100,00 & 100,00 & 99,54 & 100,00 & 99,91 \\
G & 100,00 & 99,95 & 100,00 & 83,94 & 100,00 & 96,78 \\
H & 100,00 & 99,99 & 100,00 & 98,96 & 100,00 & 99,79 \\
I & 100,00 & 99,98 & 100,00 & 99,23 & 100,00 & 99,84 \\
J & 100,00 & 99,99 & 100,00 & 99,12 & 100,00 & 99,82 \\
K & 100,00 & 99,90 & 100,00 & 97,97 & 100,00 & 99,57 \\
L & 100,00 & 99,95 & 100,00 & 98,71 & 100,00 & 99,73 \\
\hline
\end{tabular}

Sumber : data primer 
Tabel 3 Hasil analisis Man U Whitney pada masing masing filter.

\begin{tabular}{|c|c|c|c|c|c|c|c|c|}
\hline Uji Mikrobiologi & $\mathrm{N}$ & Rata2 & $\begin{array}{c}\text { Stad, De- } \\
\text { viation }\end{array}$ & Min & Maks & $\begin{array}{c}\text { Negative } \\
\text { Rank }\end{array}$ & $\begin{array}{c}\text { Positive } \\
\text { Rank }\end{array}$ & Signifikansi \\
\hline Pre Filter A & 5 & 10,664 & 8,892 & 1,33 & 21 & 5 & 0 & \multirow{2}{*}{0,042} \\
\hline Post Filter A & & 0,76 & 0,092 & 0 & 0,23 & & & \\
\hline Pre Filter B & & 14,334 & 16,597 & 1,67 & 42,33 & & & \multirow{2}{*}{0,043} \\
\hline Post Filter B & & 0,06 & 0,066 & 0 & 0,17 & & & \\
\hline Pre Filter C & & 16,668 & 14,8283 & 5,67 & 42 & & & \multirow{2}{*}{0,043} \\
\hline Post Filter C & & 0,048 & 0,044 & 0 & 0,12 & & & \\
\hline Pre Filter D & & 10,866 & 10,914 & 0,33 & 27,33 & & & \multirow{2}{*}{0,043} \\
\hline Post Filter D & & 0,026 & 0,03 & 0,01 & 0,08 & & & \\
\hline Pre Filter E & & 8,468 & 6,3032 & 0,67 & 14 & & & \multirow{2}{*}{0,043} \\
\hline Post Filter E & & 0,016 & 0,0358 & 0 & 0,08 & & & \\
\hline Pre Filter F & & 10,202 & 8,3684 & 0,67 & 20,67 & & & \multirow{2}{*}{0,043} \\
\hline Post Filter F & & 0 & 0 & 0 & 0 & & & \\
\hline Pre Filter G & & 5,268 & 4,8517 & 0,33 & 40,67 & & & \multirow{2}{*}{0,043} \\
\hline Post Filter G & & 0 & 0,0224 & 0 & 0,05 & & & \\
\hline Pre Filter H & & 13,402 & 14,246 & 0,67 & 35,33 & & & \multirow{2}{*}{0,043} \\
\hline Post Filter H & & 0,002 & 0,0045 & 0 & 0,01 & & & \\
\hline Pre Filter I & & 9,192 & 6,1143 & 1,33 & 16,67 & & & \multirow{2}{*}{0,043} \\
\hline Post Filter I & & 0,002 & 0,0045 & 0 & 0,01 & & & \\
\hline Pre Filter J & & 9,334 & 8,9139 & 0,33 & 21 & & & \multirow{2}{*}{0,043} \\
\hline Post Filter J & & 0,002 & 0,0045 & 0 & 0,01 & & & \\
\hline Pre Filter K & & 8,466 & 7,0414 & 1 & 16 & & & \multirow{2}{*}{0,043} \\
\hline Post Filter K & & 0,006 & 0,0089 & 0 & 0,02 & & & \\
\hline Pre Filter L & & 9,2 & 8,5714 & 0,67 & 22 & & & \multirow{2}{*}{0,043} \\
\hline Post Filter L & & 0,006 & 0,0134 & 0 & 0,03 & & & \\
\hline
\end{tabular}

Sumber : data primer

ga, air yang akan digunakan untuk keperluan sehari-hari berbahaya dan dapat menimbulkan penyakit infeksius. Salah satu sumber pencemar mikrobiologis karena perilaku yang tidak higienis, kebiasaan mencuci tangan sangat membantu dalam mencegah penularan bakteri dan kontaminasi bakteri. (Mirza, 2014)

Pada penelitian ini dilakukan penyaringan menggunakan air sumur, dan diamati sekaligus pada saat penyaringan adalah volume dan waktu penyaringan untuk mengetahui kemampuan saringan dalam menurunkan kandungan E coli pada air sumur yang akan digunakan sebagai air minum. Adapun hasil penyaringan dapat dilihat pada tabel berikut:

Dari tabel diatas diketahuai bahwa prosentase penurunan kadar E. coli terbesar adalah pada filter $\mathrm{F}$ dengan rata-rata prosentase penurunan E. coli $99,91 \%$ hal ini menunjukkan bahwa filter F mampu menurukan E. coli sampai dengan 99,91\%. Namun apabila dilihat secara keseluruhan penurunan E.coli pada masing masing filter mempunyai kemampuan $>90 \%$ dalam menurunkan E. coli apabila dilihat dari Nilai Pre Test dan Post Test. Kemampuan filter tersebut hampir mendekati kemampuan filter yang diteliti oleh Brown (2008) menyelidiki efektifitas saringan keramik di Kamboja yang filter keramik mereduksi E. coli dengan reduksi rata-rata $99 \%$ baik di laboratorium maupun pada percobaan di lapangan.

Untuk mengetahui kemampuan filter dalam menurukan kadar E. coli maka dilakukan analisis dengan menggunakan $t$-test terikat pada masing masing filter, adapun hasil analisis dapat disajikan pada tabel 2 berikut:

Dari tabel diatas diketahui bahwa pada semua filter mempunyai nilai signifikansi $<0,05$ yang berarti semua filter mempunyai perbedaan rerata yang signifikan pada kandungan 
Tabel 4. Hasil Analisis T-Test Bebas Kandungan E. coli Dengan Pengulangan Penyaringan

\begin{tabular}{|c|c|c|c|c|c|c|c|c|c|}
\hline \multirow[t]{2}{*}{ Filter } & \multirow[t]{2}{*}{$\mathrm{N}$} & \multirow[t]{2}{*}{ Mean } & \multirow{2}{*}{$\begin{array}{c}\text { Stad, } \\
\text { Deviation }\end{array}$} & \multirow{2}{*}{$\begin{array}{l}\text { Std, } \\
\text { Error }\end{array}$} & \multicolumn{2}{|c|}{$\begin{array}{l}\text { 95\% Confidance } \\
\text { Interval }\end{array}$} & \multirow[t]{2}{*}{ Minimum } & \multirow[t]{2}{*}{ Maksimum } & \multirow[t]{2}{*}{ Signifikansi } \\
\hline & & & & & Lower & Upper & & & \\
\hline A & 5 & 98,738 & 1,00964 & 0,45152 & 97,4844 & 99,9916 & 97,7 & 99,99 & 0,622 \\
\hline B & 5 & 99,146 & 0,71731 & 0,32079 & 98,2553 & 100,0367 & 98,45 & 100 & \\
\hline C & 5 & 99,558 & 0,36772 & 0,16445 & 99,1014 & 100,0146 & 99,16 & 99,99 & \\
\hline $\mathrm{D}$ & 5 & 98,856 & 1,65281 & 0,73916 & 96,8038 & 100,9082 & 95,96 & 99,97 & \\
\hline $\mathrm{E}$ & 5 & 99,8 & 0,29908 & 0,13375 & 99,4286 & 100,1714 & 99,33 & 100 & \\
\hline $\mathrm{F}$ & 5 & 99,908 & 0,20572 & 0,092 & 99,6526 & 100,1634 & 99,54 & 100 & \\
\hline G & 5 & 96,778 & 7,17669 & 3,20951 & 87,867 & 105,689 & 83,94 & 100 & \\
\hline $\mathrm{H}$ & 5 & 99,79 & 0,464 & 0,20751 & 99,2139 & 100,3661 & 98,96 & 100 & \\
\hline I & 5 & 99,842 & 0,34223 & 0,15305 & 99,4171 & 100,2669 & 99,23 & 100 & \\
\hline $\mathrm{J}$ & 5 & 99,822 & 0,39245 & 0,17551 & 99,3347 & 100,3093 & 99,12 & 100 & \\
\hline K & 5 & 99,574 & 0,89771 & 0,40147 & 98,4593 & 100,6887 & 97,97 & 100 & \\
\hline $\mathrm{L}$ & 5 & 99,732 & 0,57173 & 0,25568 & 99,0221 & 100,4419 & 98,71 & 100 & \\
\hline
\end{tabular}

Sumber : data primer

E. coli sebelum dan sesudah penyaringan dengan menggunakan filter keramik. Sedangkan apabila membandingkan kemampuan masing masing filter dalam menurunkan E. coli maka dapat disajikan pada tabel 3:

Dari tabel diatas diketahui bahwa kemampuan filter pada setiap perulangan tidak menunjukkan beda yang bermakna ditunjukkan dengan nilai signifikasi $>0,05$ sedangkan pada uji beda pada masing masing filter ditunjukkan dengan tabel 4:

Tabel 5. Hasil Uji Korelasi Regresi Jenis Filter Dengan Kandungan E. coli

\begin{tabular}{llc|}
\hline \multirow{2}{*}{ Filter } & Indikator Pengujian & Uji Mikrobiologi \\
\cline { 2 - 3 } & Pearson Correlation & 0,26 \\
\cline { 2 - 3 } & Sig. (2-tailed) & 0,414 \\
\cline { 2 - 3 } $\mathrm{N}$ & 12 \\
\hline
\end{tabular}

Sumber : data primer

Dari tabel 4 di atas diketahui bahwa tidak ada perbedaan kemampuan masing masing filter dalam menurunkan kadar E. coli, hal ini dilihat dari nilai signifikansi sebesar 0,414>0,05 Secara umum kemampuan semua filter yang diuji sama, sehingga dalam menentukan pilihan filter yang akan dikembangkan dapat didasarkan pada segi efektif dan efisiensi pada biaya pembuatan dan biaya proses, sehingga diperoleh filter yang mempunyai cost lebih murah namun kemampuan yang sama. Sistem penyaringan air keramik umumnya terdiri dari membran keramik berpori, plastik atau wadah keramik, dan keran plastik. Kepadatan dan ukuran pori-pori filter adalah dua faktor yang mempengaruhi penyaring kinerja (Hagan, 2009). Saringan keramik dengan perak efektif menonaktifkan 98-100\% dari E. coli, Cryptosporidium, dan Giardia. Filter keramik dapat menjadi sebuah teknologi yang efektif dan tepat guna yang meningkatkan baik kualitas air dan kesehatan manusia.

Manfaat utama dan kelemahan filtrasi keramik sebagai metode pengolahan air rumah tangga tercantum dalam Tabel 6 yang diadaptasi dari lembar fakta CDC pada filtrasi keramik. Hal tersebut penting untuk dipertimbangkan sebelum merancang implementasi filter keramik. Keuntungan dalam saringan keramik adalah pembuatan menggunakan bahan-bahan lokal.

Sebagian besar studi yang dilakukan dalam menilai kinerja filter keramik diketahui bahwa filter keramik menjadi sangat efektif dalam menghilangkan E.coli dan coliform dari air yang diolah. (Clasen, 2004). Salah satu keunggulan filter keramik untuk diproduksi di Daerah Istimewa Yogyakarta adalah tersedia bahan lokal, dan Grog sendiri sebagai penyusun utama filter sebenarnya adalah limbah yang dihasilkan dari industri genteng yang merupakan home industri dan terdapat di wilayah sleman bagian barat. 
Tabel 6. Manfaat dan kerugian menggunakan filter keramik

\begin{tabular}{ll}
\hline \multicolumn{1}{c}{ Manfaat } & \multicolumn{1}{c}{ Kerugian } \\
\hline $\begin{array}{l}\text { Terbukti efektif dalam menghilangkan bakteri dan } \\
\text { protozoa mengakibatkan pengurangan diare sebesar } \\
60-70 \%\end{array}$ & penghapusan Terbatas virus, logam berat, dan pestisida \\
$\begin{array}{l}\text { Dapat meningkatkan rasa dan bau dari air dan mengu- } \\
\text { rangi kekeruhan }\end{array}$ & $\begin{array}{l}\text { Air dapat menjadi terkontaminasi kembali karena ada } \\
\text { ada perlindungan residual }\end{array}$ \\
$\begin{array}{l}\text { Manfaatkan bahan lokal dan pengetahuan lokal yang } \\
\text { ada }\end{array}$ & Kualitas Filter dapat bervariasi menurut wilayah \\
Satu kali investasi berkisar 12-60 USD & harga awal bisa relatif tinggi \\
& $\begin{array}{l}\text { Mudah digunakan, membran keramik rapuh dan keran } \\
\text { dapat bocor }\end{array}$ \\
& $\begin{array}{l}\text { Sederhana untuk mempertahankan tingkat Laju filtrasi, } \\
1-3 \text { liter per Jam (L / H) }\end{array}$ \\
& Rentang hidup yang efektif filter tidak diketahui \\
\end{tabular}

Sumber : data primer

\section{Penutup}

Penelitian ini menunjukkan tidak Ada perbedaan rerata penurunan kadar E. coli pada metode I, Metode II, dan Metode III aplikasi perak nitrat pada saringan desain SHEEP. Berdasar pada hasil penelitian ini, maka semua metode penambahan perak nitrat yang diaplikasikan dapat dijadikan alternative dalam proses pembuatan filter. Pertimbangan yang selanjutnya yang harus digunakan dalam penentuan jenis filter yang akan diproduksi adalah variabel biaya produksi, residu perak dan residu nitrat, untuk itu peneliti menyarankan untuk dilaksanakan penelitian lebih lanjut dengan memperhatikan variabel tersebut sebelum dilakukan produksi.

Penulis mengucapkan terima kasih kepada Rektor UGM, Dekan Fakultas Kedokteran UGM, Direktur Pasca sarja FK UGM, Kepala Laboratorium Mikrobiologi FK UGM, Ketua Jurusan Teknik Kimia, dan Direktur Yayasan SHEEP Indonesia yang telah memberikan kesempatan dan memberikan dukungan kepada penulis untuk melaksanakan penelitian ini.

\section{Daftar Pustaka}

Amber, Farroqui. 2009. Investigation of a community outbreak of typhoid fever associated with drinkin water. BMC Public Health, 9:476
Brown, J.,Sobsey, M.D. and Loomis, D. 2008. Local Dinking water filters reduce diarrheal disease in Cambodia: a randomized controllrd trial of the ceramic water purifier, The American Journal of tropical medicine and hygiene, 79 (3), 394-400

Clasen, TF., Brown, J., Collin, S., Suntura, O. and Cairncross, S. 2004. Reducing diarrhea through the use of household-based ceramic water filters; Arandomized, Controlled trial in rural Bolivia. The American journal of tropical medicine and hygiene, 70 (6), 651-657

Clasen, T., W. P. Schmidt, T. Rabie, I. Roberts \& S. Cairncross. 2007, Interventions to improve water quality for preventing diarrhoea: systematic review and metaanalysis. BMJ, 334 (7597), 782

Hagan, J., N. Harley, D. Pointin, M. Sampson, S. Vanna \& K. Smith. 2009. Resource Development International- Cambodia: Ceramic Water Filter Handbook.

Jung, W.K., Koo, H.C., Kim, K.W., Shin, S., Kim, S.H, Park, Y.H. 2008. Anti bacterial activity and mechanism of antion of the silver ion in sthapylococcus aureus and Esherecia coli, Applied and environmental Microbiology, 74: 2171-2178

Mirza, Muhammad Navis. 2014. Higiene sanitasi dan Jumlah Coliform air minum, Kemas Jurnal Kesehatan Masyarakat, 2: 167-173

Sukarma., R. 2009. Pengolahan Air Sederhana dengan Saringan Keramik, Hasil Riset dan Penelitian, Opini 